\title{
MILITANTNOST U DEMOKRATIJI
}

\section{Uvod}

Demokratija je oblik vladavine koji čini jedan društveni poredak civilizovanim i modernim. Danas se sve više država proglašava demokratskim društvima sa demokratskim ustavnim poretkom.

Savremeni ustavi ne sadrže definiciju demokratije niti je na drugi način opisuju, ona proizlazi iz različitih prava i načela sadržanih u domaćim pozitivnim pravnim propisima kojima se deklarišu i štite, jer demokratija nije i ne može biti svedena na ustavnu odredbu.

Da bi se održao jedan demokratski ustavni poredak nije dovoljno samo usvojiti načela slobode i jednakosti i zakonima propisati odgovarajuća pravila ponašanja. Neophodne su preventivne mere radi odbrane od ekstremističkih delovanja partija, terorističkih napada i drugih oblika narušavanja demokratskog poretka i pre nego što dođe do njegovog ugrožavanja.

Militantna demokratija se pojavila kao pojmovni paradoks samoj demokratiji, jer demokratija u svom idealističkom konceptu slobode i jednakosti svih ljudi ne sadrži mere za njihovo ograničavanje. Kako zaštititi demokratiju u granicama demokratije? Da li je demokratija kao oblik vladavine održiva bez militantnih mera?

\section{Pojam DEmokratije}

Demokratija je politički oblik vladavine u kojem vlast potiče od naroda i predstavlja vladavinu većine. Naziv je grčkog porekla dēmokratía, odnosno „vladavina naroda“ i predstavlja složenicu reči dêmos „narod“ i $\kappa \rho \alpha ́$ ¿ Demokratija, kao prihvaćeni politički sistem, prvi put se javlja između 5. i 4. veka pre nove ere u grčkim gradovima-državama. ${ }^{1}$

Vekovima se demokratija različito tumači i poprima različite oblike. Monteskje predstavlja demokratiju kao vladavinu privilegovanih, a francuski teoretičar Žan-Žak Ruso kao "generalnu volju“ svih ljudi zasnovanu na

\footnotetext{
* Studentkinja master studija Pravnog fakulteta Univerziteta Union u Beogradu

1 Wikipedia, http://en.wikipedia.org/wiki/Demokratia, 9. mart 2011.
} 
njihovoj jednakosti, što je bilo nadahnuće za tri osnovna postulata francuske države „slobodu, jednakost i bratstvo“.2

I pored različitih viševekovnih analiza, još nije usvojena univerzalno prihvaćena definicija demokratije. Sloboda i jednakost, osnovne vrednosti demokratije, ostale su nepromenjene od antičkih vremena do danas.

Ustavnost proizlazi iz modernog shvatanja demokratije. Savremena ustavnost podrazumeva poštovanje principa: narod je izvor suverenosti, vladavine prava, sistema podele vlasti na zakonodavnu, izvršnu i sudsku, nezavisnosti pravosuđa, sistema ravnoteže i međusobne kontrole, političkog pluralizma, poštovanja individualnih prava i sloboda, kao i prava na samoopredeljenje. ${ }^{3}$

Upravo su to principi demokratije koji predstavljaju protivtežu apsolutističkom, totalitarnom, autokratskom, diktatorskom režimu i svim ostalim režimima u kojima sredstva za opstanak na vlasti nisu bila birana. To su režimi u kojima je vlast, odnosno korist vladara ili vladajuće manjine imala primat, a narod bio samo puko kontrolisano sredstvo za iskorišćavanje, lišen sloboda i prava izbora ili sa prividno priznatim slobodama i pravom izbora.

Uspostavljanje demokratskog poretka i sistema društvenih vrednosti u svakoj zemlji bilo je drugačije zbog različitih političkih i istorijskih okolnosti. Jednom uspostavljena demokratija ne podrazumeva njen večan opstanak, niti isključuje borbu za vlast, odnosno napade pristalica suštinsko drugačijih režima. Problem zaštite demokratije jeste problem sa kojim se države stalno suočavaju.

\section{Nastanak ideje o militantnoj Demokratiji}

Demokratija se zasniva na garancijama individualnih sloboda i jednakosti, pa ipak sloboda može biti upotrebljena i protiv nje u cilju njenog uništenja. ${ }^{4}$ Da li je samo apsolutna sloboda u službi demokratije?

Ova pitanja, koja su usledila sa idejom o militantnoj demokratiji Karla Levenštajna (Karl Loewenstain) i Karla Manhajma (Karl Mannheim), uvedena su u ustavnopravnu praksu i unesena u Osnovni zakon Savezne Republike Nemačke. Militantna demokratija je politička pouka vezana za propast Vajmarske Republike i Vajmarskog ustava, kao i za brz i lak dolazak nacista na vlast.

Koncept militantne demokratije pridaje određenim vrednostima posebno značenje jer polazi od toga da u sukobu sa političkim ekstremizmom samo država koja se veže za određene vrednosti, odnosno demokratija koja bar malo nije učvršćena u narodu ne može biti uspešno branjena. Ustav Vajmar-

2 Rosenfeld, Sajo, Dorsen and Baer, Comparative Constitutionalism: Cases and Materials, American Casebook Series 2010, str. 1267.

3 Rosenfeld, Sajo, Dorsen and Baer, op. cit., str. 12-13.

4 Ibid., str. 1276. 
ske Republike se nije držao takvog koncepta, te je omogućavao da se dvotrećinskom većinom glasova u skupštini mogu menjati ustavne odredbe, što je i olakšalo ustoličavanje nacionalsocijalista na vlast 1933. godine.

Vajmarska Republika je trajala od 1919. do 1933. godine, a njen dobar period vezuje se za uspostavljanje političke stabilnosti, privredni oporavak i kulturni procvat. U 1919. godini, došlo je do velikih promena u socijalnoj politici - sindikati su dobili pravo glasa pri utvrđivanju dnevnica i uslova rada, dok su žene dobile aktivno i pasivno biračko pravo i iste godine je izabrana prva žena za poslanika u skupštini.

Ekonomska kriza i masovna nezaposlenost koja je nastupila 1929. godine, a samim tim i nepoverenje naroda u demokratiju, ustavni nedostaci, kao i nepostojanje saradnje između stranaka prethodili su slomu Vajmarske Republike. Izbori 1933. godine doveli su na vlast Nacionalnu socijalističku nemačku radničku partiju i Nemačku nacionalnu stranku. Uspostavljena je jednostranačka država i diktatorski režim Hitlera, čija je vladavina ostala upamćena po genocidu nad Jevrejima i po Drugom svetskom ratu koji je prouzrokovao mnogobrojne ljudske žrtve i velike materijalne gubitke.

Nakon završetka Drugog svetskog rata, Nemačka je podeljena na istočni i zapadni blok. U istočnom delu je bila komunistička diktatura, a u zapadnom Savezna Republika Nemačka koja je bila pod američkim okriljem. Godine 1949, Savezna Republika Nemačka donosi Osnovni zakon, koji je predstavljao privremeni ustav zapadnog dela, ali je opstao uz brojne izmene i dopune i nakon ujedinjenja dva bloka. U Osnovnom zakonu se ne pominje pojam militantne demokratije, ali se Savezni ustavni sud Nemačke poziva na njega u obrazloženjima odluka kojima zabranjuje Socijalističku partiju, koja je „nastojala da utiče na liberalno-demokratski poredak “. ${ }^{\circ}$

Karl Levenštajn je smatrao da je demokratija Vajmarske Republike unapred bila osuđena na propast jer nije bila militantna, odnosno nije bila sposobna da se brani od političkog ekstremizma. On je prvi put, 1937. godine, predstavio koncept militantne demokratije u kojem je lišavanje prava njenim protivnicima nužno radi zaštite demokratskog sistema.

Totalno suprotno stanovište zastupali su Hans Kelzen (Hans Kelsen) i Gustav Radbruh (Gustav Radbruch) kao pobornici demokratije koja mora ostati dosledna sebi, koja predstavlja sistem vrednosti u kome politički stav svakog pojedinca zaslužuje isto poštovanje. „Demokratija koja se pokušava suprotstaviti želji većine, pa i silom, prestaje biti demokratija. Vladavina naroda ne može opstati protiv naroda... Ko je za demokratiju ne sme se zaplesti u kobno protivrečje i posegnuti za diktaturom kako bi spasao demokratiju. Mora se ostati veran zastavi, čak i kad brod tone..."6

5 Rosenfeld, Sajo, Dorsen and Baer, op. cit., str. 1276.

6 Damir Velički, Koncept „borbene demokratije“ u SR Nemačkoj, Politička misao, broj 4, Vol. XLIV 2007, str. 41. 


\section{Demokratska dilema}

Problem ograničavanja političkih sloboda u svrhu zaštite demokratskog poretka Levenštajn opisuje demokratskom dilemom: „Ako demokratska država odluči da se brani svim sredstvima i da uskrati totalitarnim napadačima uživanje demokratskih sloboda, postupa protivno načelima slobode na kojima i sama počiva. Ako pak ostane dosledna osnovnim demokratskim načelima i u korist svojih zakletih neprijatelja, tada stavlja na kocku i vlastitu egzistenciju."

Pojam militantne demokratije pojavio se prvi put 1956. godine u obrazloženju zabrane Komunističke nemačke partije, u težnji za uspostavljanjem ravnoteže „tolerancije prema svim političkim mišljenjima i izjašnjavanjem za određene nepovredive vrednosti državnog uređenja“. Cilj ovog koncepta je bio zaštita demokratskog poretka Savezne Republike Nemačke koji je postavio Savezni ustavni sud još 1952. godine zabranjivanjem delovanja Socijalističke stranke. Prilikom zabranjivanja Komunističke partije, Savezni Ustavni sud je precizirao zahteve za zabranu stranaka, određujući da stranka nije protivustavna samim tim što ne priznaje načela demokratije, već ako ima agresivan stav prema demokratskom poretku i ako deluje sa namerom da isti poredak oslabi i konačno smeni.

Socijalistička partija je bila naslednik nemačke vladajuće stranke koja je bila neonacistički orijentisana. Stranka je imala unutrašnju organizaciju sličnu nacističkoj sa bivšim nacistima na rukovodećim mestima. Savezni ustavni sud Nemačke je raspustio stranku, polazeći sa stanovišta da teži slabljenju slobodnog demokratskog poretka i uvidevši da je unutrašnja struktura stranke nedemokratska.

Savezni ustavni sud se našao pred „demokratskom dilemom“ na koju je ukazao Levenštajn 1937. godine - demokratija postupa suprotno svojim principima ukoliko uskraćuje napadačima uživanje demokratskih sloboda, a ugrožava svoj opstanak dosledno ih poštujući.

U slobodnim demokratskim državama sloboda političkog mišljenja i sloboda političkog organizovanja garantovane su svim građanima kao osnovno pravo. Političko pravo da se bira i bude biran ostvaruje se kroz političke partije. Ustavni sud Nemačke se našao pred „dilemom“ da se vladajući princip demokratije, apsolutna sloboda u vezi sa osnivanjem političkih partija, ograniči bez obzira na njihov program.

Uvidevši specijalnu ulogu stranaka u demokratskoj državi, Savezni ustavni sud je odlučio da je opravdano eliminisanje sa političke scene samo ukoliko su stranke nastrojene da sruše uzvišene osnovne vrednosti slobodnog demokratskog poretka koje su utvrđene ustavom. Pri sagledavanju konačnog cilja stranke, morala se obratiti pažnja i na njenu unutrašnju organizaciju. Članovi stranke ne smeju biti isključeni iz procesa donošenja odluka, pri tom moraju da budu jednaki i uvek slobodni da se učlane u stranku, kao i da je napuste. 
Ukoliko stranka nije demokratski uređena, može se postaviti pretpostavka da stranka želi da reflektuje svoju unutrašnju organizaciju i na državni nivo. Naravno, ovakva pretpostavka bi se morala utvrđivati u svakom pojedinačnom slučaju. $^{7}$

Karl Poper (Karl Popper) govori o „paradoksu tolerancije“, odnosno da je protivrečnost demokratije mogućnost da se slobodni građani odluče za vladavinu neslobode i da se demokratija ne može braniti bez ograničenja političkih sloboda. $^{8}$

\section{Slučaj Partije prosperiteta (Refah Partisi)}

U slučaju Partije prosperiteta (Refah Partisi), Ustavni sud Turske je raspustio ovu političku partiju 1998. godine i pored toga što je bila najveća partija u turskom parlamentu 1995. i član koalicione vlade 1996. godine, jer je bila centar aktivnosti koje su suprotne sekularizmu. Unutrašnja organizacija nije bila nedemokratska, ali su njeni istaknuti članovi zastupali stav da sve žene treba da nose feredže na javnim mestima, iako je to bilo suprotno Ustavu, raspravljali su o tome da li će društvene promene kojima partija teži biti „nasilne ili mirne", težeći da uspostave suprematiju Kurana putem džihada - svetog rata i konačnog uvođenja teokratskog režima. Partija prosperiteta je smatrala da odluka predstavlja povredu prava na političko okupljanje zagarantovano Evropskom konvecijom o ljudskim pravima.

Vladavina prava podrazumeva da su svi ljudi jednaki pred zakonom u njihovim pravima i obavezama. Nema vladavine prava u društvima gde su grupe ljudi diskriminisane isključivo na osnovu pripadnosti istom polu ili imaju drugačija politička i religiozna opredeljenja, ili gde je čitav pravni sistem podređen takvim grupama.

Sud je zauzeo stanovište da političke stranke mogu da se zalažu za promenu zakonskih i ustavnih odredaba ispunjavajući dva uslova: sredstva zalaganja moraju biti legalna i demokratska, a predložene promene moraju biti kompatibilne sa osnovnim demokratskim principima.

Sud insistira na tome da su sloboda misli, svesti i veroispovesti jedan od temelja demokratskog društva, zagarantovane Konvencijom. Pluralizam je neodvojiv od demokratskog poretka, koji podržava slobodu da se bude vernik ili ne i da neko lice živi ili ne živi u skladu sa verom. Država je dužna da obezbedi religijsku harmoniju i toleranciju u društvu!

Vođena iskustvom teokratskog režima tokom Otomanskog carstva, Turska je stvorila sekularni republikanski režim tako što je stala na put teokratiji. Društveni model koji je predložila Partija prosperiteta u kojem postoji plu-

7 Rosenfeld, Sajo, Dorsen and Baer, op. cit., str. 1278.

8 Damir Velički, op. cit., str. 1. 
ralitet u pravnom sistemu, odnosno u kojem se u sve pravne odnose uvodi razlika među pojedincima na osnovu religije, nije kompatibilan sa Konvencijom. Država kao potpisnica Konvencije ima pozitivnu obavezu da obezbedi svakome da uživa prava i slobode koje su njom propisane. Lideri Partije prosperiteta se nisu u svojim zvaničnim dokumentima pozivali na upotrebu sile i nasilja kao političkog sredstva, ali se nisu ni distancirali od izjava svojih članova koji su javno propagirali dozvolu upotrebe sile protiv neistomišljenika. Sud je ocenio da ciljevi Partije prosperiteta nisu bili iluzorni već mogući za realizaciju.

Kako je politički pluralitet neodvojiv od demokratskog sistema, konačna odluka Suda zasnivala se na tome da država mora odgovorno da postupa i preduhitri svaku politiku, poput politike Partije prosperiteta, koja je u suprotnosti sa Konvencijom, pre stvarnog pokušaja da takva politika ugrozi društveni mir i državni demokratski poredak.

Militantna demokratija može da ide i dotle da ukine partiju koja je ušla u koaliciju, iako u njenom programu nema ničeg nedemokratskog niti protivnog sekularizmu. Ovakvo postupanje Suda jeste u duhu militantne demokratije, odnosno reč je o preventivnoj zaštiti demokratije koja se brani od ekstremističkih pozicija i pre nego što ekstremističke grupacije prekrše zakon. ${ }^{9}$

Evropski sud za ljudska prava je našao da je turski sud prekršio Konvenciju u pogledu zaštite ljudskih prava i osnovnih sloboda. Ustavni sud Turske je ukinuo Ujedinjenu komunističku partiju jer je težila dominaciji jedne klase nad drugom, protivzakonito koristila reč „komunistička“ u svom imenu i propagirala nezavisnost Kurda i time, protivno Ustavu i zakonu, podrivala teritorijalni integritet i jedinstvo nacije. „Ne postoji opravdanje za zabranu neke političke grupe samo zato što zahteva javnu debatu u vezi sa situacijom stanovništva i zato što učestvuje u političkom životu države i pokušava da pronađe rešenja za svakoga na koga se odnose, u skladu sa svim demokratskim pravilima."

Evropska konvencija o ljudskim pravima priznaje demokratiju kao jedini politički oblik vladavine u skladu sa njom i njenim odredbama! ${ }^{10}$

„Demokratija počiva na jednakim pravima glasa, ali je suštinski bazirana na ideji individualnog samoopredeljenja, samim tim i na slobodi. Ukoliko su ljudi slobodni da biraju, da li mogu da izaberu nedemokratski poredak? Da li demokratija može da izdrži toleranciju prema neprijateljima?"11 Lord Ekšn (Lord Action) kaže: „da će u jednom periodu tolerancija uništiti društvo, u drugom, njen nedostatak je koban za slobodu“. 12

9 Damir Velički, op. cit., str. 1.

10 Rosenfeld, Sajo, Dorsen and Baer, op. cit., str. 1279.

11 Ibid., str. 1270.

12 András Sajó, From militant democracy to the preventive state, str. 2262, dostupno na: www.cardozolawreview.com/content/27-5/SAJO. WEBSITE.pdf, 9. mart 2010. 


\section{Lustracija}

Države koje su skoro uvele demokratiju kao oblik vladavine poznaju institut lustracije koja je uvedena u cilju zaštite mladog demokratskog poretka, iako je stanovište nekih političara da je lustracija odmazda prema političkim neistomišljenicima.

Vesna Rakić-Vodinelić smatra o lustraciji sledeće: „Suština pravne diskvalifikacije kao posledice lustracijskog procesa sastoji se u tome što onom javnom funkcioneru koji je masovno kršio ljudska prava ne treba poveriti odlučivanje o tim pravima zato što je izgubio javno poverenje, pa se od njega ne može očekivati da ljudska prava profesionalno štiti. "13

U Gambiji se pokušaj lustracije završio samo pokušajem da se Omaru Dželouvu (Omar Jallow), kao bivšem ministru, zabrani dalje političko delovanje u novoj vladi. Gambija je potpisnica Međunarodnog pakta za građanska i politička prava i članica Afričkog saveza ljudskih prava koja garantuju slobodu izražavanja i udruživanja. Dekret 89 , koji lišava određene osobe prava da se bave politikom i na osnovu koga je Omar trebalo da bude smenjen, smatran je neusklađenim sa Ustavom i internacionalnim ljudskim pravima na koje se Gambija obavezala.

Ustavni sud Mađarske je smatrao da lustracija ne treba da bude cenjena po izuzetnim uslovima tranzicije, već da treba da se otvore lični dosijei. Pravo je glasača da imaju pristup informacijama od javnog značaja koje jesu prednost u odnosu na zaštitu dosijea osoba sa ključnim političkim ulogama ili službenika, jer bi narod na osnovu njih formirao vlast. ${ }^{14}$

\section{ZAKLJUČAK}

Zaštita u društvu koje poštuje osnovne demokratske vrednosti, u kom se svakom pojedincu priznaje sloboda udruživanja i političkog delovanja, ne može samo biti u rukama države, jer je najbolja zaštita demokratskog ustavnog poretka upravo međusobna tolerancija građana i njihova spremnost da se zalažu za vrednosti demokratije. Takvi građani mogu da se suprotstave državi ako se krše njihova prava, a delovanja ekstremističkih partija ili drugih organizacija koje imaju za cilj rušenje demokratskog poretka svela bi se na minimum. Građani koji žele da žive u poretku koji je zasnovan na garantijama osnovnih ljudskih prava i sloboda manje bi potpadali pod uticaj takvog delovanja, takvim narodom ne bi bilo lako manipulisati. Svoja prava bi ostva-

13 Vesna Rakić-Vodinelić, Neuspešan pokušaj lustracije u Srbiji, Hereticus, broj 2/2003, str. 70-71, dostupno na: www.hereticus.org/.../neuspesan-pokusaj-lustracije-u-srbiji. html, 9. mart 2011.

14 Rosenfeld, Sajo, Dorsen and Baer, op. cit., str. 1275. 
rivali u demokratski priznatim procedurama, a ne nasiljem, govorom mržnje, pozivanjem na diskriminaciju, rasnom i verskom netrpeljivošću...

Demokratski poredak ipak poznaje granice slobode: „Granice slobodama i pravima građana predstavljaju samo iste takve slobode i prava drugih građana kao i ustavom navedeni opšti interesi zajednice."15

Ustavne države se štite kroz pravnu zaštitu koja se zasniva na prezumpciji ugroženosti. Tradicionalne manifestacije militantne demokratije ogledaju se u zabrani govora mržnje, ograničavanja masovnih demonstracija, zabrani delovanja pojedinih političkih grupa...

Mere koje se uvode u cilju borbe protiv ekstremističkih političkih programa koji ugrožavaju mir, bezbednost, demokratski poredak, svakako ometaju vršenje pojedinih ljudskih prava (kao što su sloboda izražavanja, mišljenja, religije i udruživanja), a sve u ime demokratskog samoodržanja. ${ }^{16}$

Prema Koenu (Cohen) „najbrži i najsigurniji način da nađete sadašnjost u prošlosti, jeste da je stavite ispred prošlosti “. ${ }^{17}$

Demokratija u svom izvornom obliku, sa svojim glavnim odlikama jednakošću i slobodom koja ne poznaje granice, nema potrebe da bude ni defanzivna ni ofanzivna, te ostaje za sada samo ideal kome se teži.

15 Marjana Pajvančić, Ustavno pravo - ustavne institucije, Novi Sad 2003, str. 158.

16 Patrick Macklem, Militant Democracy, legal pluralism and paradox of self-determination, Legal studies research paper, No. 05-03, str. 1-2.

17 Todor Kuljić, Pregledavanje prošlosti, Beograd 2002, str. 1. 